\title{
Aplikasi Agarosa Sebagai Matriks Kultur 3d Pada Sel Kanker Paru Line A549
}

\author{
Suci Rahmawati ${ }^{*}$, Adek Zamrud Adnan', Muhammad Taher ${ }^{3}$, Marlina ${ }^{2}$ \\ ${ }^{1}$ Program Studi D3 Farmasi, Fakultas Matematika dan Ilmu Pengetahuan Alam, \\ Universitas Bengkulu \\ ${ }^{2}$ Fakultas Farmasi, Universitas Andalas \\ ${ }^{3}$ Faculty of Pharmacy, International Islamic University Malaysia (IIUM) \\ Email: srahmawati@unib.ac.id
}

\begin{abstract}
ABSTRAK
Agarosa merupakan salah satu biopolimer yang sering digunakan dalam bidang bioteknologi, diantaranya sebagai matriks pada kultur sel. Penelitian ini bertujuan untuk mengaplikasikan agarosa hasil isolasi dari tepung agar sebagai matriks kultur 3D pada sel kanker paru line A549. Hasil isolasi diperoleh Agarosa 1 (A1) dan Agarosa 2 (A2) hasil pemurnian dari A1. A1 dan A2 dengan konsentrasi 5\% diaplikasikan sebagai matriks kultur 3D di dalam well plate kultur sel kanker paru line A549 dengan densitas $10^{7}$, sebagai kontrol pertumbuhan digunakan kultur 2D sel (well plate tanpa matriks) dan kontrol positif kultur 3D sel pada matriks agarosa Top Vision ${ }^{\circledR}$. Viabilitas sel diamati pada hari ke 2, 4 dan 6 menggunakan pewarna trypan blue. Proliferasi sel diamati pada hari ke 6 menggunakan reagen MTT. Hasil uji viabilitas terlihat agregat sel 3D pada matriks agarosa yang viable dan tidak menyerap warna trypan blue. Viabilitas sel dibuktikan dengan uji proliferasi dan diperoleh nilai ratarata absorban pada kultur 2D, kultur 3D matriks kontrol, A1 dan A2 masing-masingnya 2.03; $1.21 ; 0.96$ dan 1.22. Proliferasi kultur 2D lebih baik dari 3D, akan tetapi proliferasi kultur 3D pada matriks A2 lebih baik dari matriks kontrol. Pada penelitian ini dapat disimpulkan bahwa agarosa dapat diaplikasikan sebagai matriks kultur 3D sel.
\end{abstract}

Kata Kunci: Agarosa, Kultur 3D Sel, Sel Kanker Paru

\section{Application Of Agarose As 3d Culture Matrix For A549 Cell Line Of Lung Cancer Cell}

\begin{abstract}
Agarose is one of biopolymer that used in biotechnology, referred to as a matrix in cell culture. This research was aimed to apply agarose which isolated from agar flour as 3D culture matrix in A549 line lung cancer cells. Isolation was obtained Agarose 1 (A1) with $81.49 \%$ of yield and Agarose 2 (A2) as result of refining from A1 with $79.74 \%$ of yield. A1 and $\mathrm{A} 2$ with $5 \%$ of concentration were applied as $3 \mathrm{D}$ culture matrices in cell culture plates of A549 line lung cancer cells with $10^{7}$ of its density, as a growth control used 2D cell cultures (well plates without polymers) and positive control of $3 \mathrm{D}$ cell cultures on Top Vision ${ }^{\circledR}$ agarose matrix. Cell viability was viewed on days 2, 4 and 6 using trypan blue dye and cell proliferation was chosen on day 6 using MTT reagent. The viability test was saw 3D cell agregate on viable agarose matrix and doesn't absorb trypan blue color. Cell viability was proven by proliferation test and obtained the average value of absorbance in $2 \mathrm{D}$ culture, $3 \mathrm{D}$ culture matrix control, A1 and A2, respectively 2.03;1.21;0.96 and 1.22. The proliferation of $2 \mathrm{D}$ cell culture is better than $3 \mathrm{D}$ cell, but proliferation of $3 \mathrm{D}$ cell culture on the $\mathrm{A} 2$ matrix is
\end{abstract}


better than matrix control. In this study was can be concluded that agarose can be applied as 3D cell culture matrix.

Key words: Agarose, 3D cell culture, Lung cancer cell

\section{Pendahuluan}

Agarosa memiliki banyak manfaat dalam penelitian di bidang mikrobiolgi maupun bioteknologi. Salah satu pemanfaatan agarosa yang akhir-akhir ini dikembangkan adalah agarosa sebagai matriks pada kultur sel 3D. Kultur sel 3D memberikan gambaran bentuk sel yang hampir sama persis dengan kondisi sel di dalam tubuh. Hal ini akan berdampak pada ekspresi gen yang lebih baik dari kultur sel 2D, sehingga hasil pada percobaan uji aktivitas biologi yang lebih tepat (Santos, 1990; Edmondson dkk, 2014; Mishra dkk, 2014).

Matriks kultur sel 3D harus menjamin nutrisi pada sel dapat berdifusi dengan baik, sehingga sel pada kultur 3D dapat berkembang baik. Agarosa dalam beberapa penelitian telah diuji sebagai matriks dan hasilnya pertumbuhan sel pada kultur 3D menggunakan matriks agarosa mampu berproliferasi lebih baik bila dibandingkan dengan kultur sel 2D. Hal ini karena agarosa dalam bentuk mold bersifat netral dan dapat mendifusikan nutrisi pada media untuk pertumbuhan sel 3D ( $\mathrm{Li} \mathrm{dkk}$, 2012; Xu dkk, 2014)

Pada penelitian ini dilakukan pengujian pemanfaatan agarosa sebagi matriks kultur sel 3D pada sel kanker paru line A549. Sel ditanamkan ke dalam matriks agarosa di dalam well, dilakukan pengujian viabilitas sel menggunakan pewarna trypan dan uji proliferasi sel menggunakan reagen MTT. Penelitian ini bertujuan untuk mengaplikasikan agarosa hasil isolasi dari agar sebagai matriks kultur sel 3D pada sel kanker paru line A549.

\section{Metode Penelitian}

Agarosa

Pada penelitian ini digunakan agarosa hasil isolasi (A1) dan pemurnian (A2) dari tepung agar produksi PT. Satelit Sriti.

\section{Kultur sel}

Sel kanker paru line A549 diperoleh dari koleksi Assoc Prof. Dr. Solachuddin J. Ichwan, di Kulliyah of Dentistry, International Islamic University of Malaysia, Kuantan, Malaysia.

\section{Pembuatan Matriks Agarosa}

Matriks untuk kultur sel 3D digunakan agarosa hasil isolasi (A1) dan agarosa hasil pemurnian (A2) dalam konsentrasi 5\% (5 gram agarosa dilarutkan dalam $100 \mathrm{~mL}$ aquadest). $20 \mu \mathrm{L}$ matriks dipipetkan ke dalam well (96 well), secara cepat $10 \mu \mathrm{L}$ sel dengan densitas $10^{7}$ disuspensikan ke dalam well berisi matriks. Setelah membentuk gel, $20 \mu \mathrm{L}$ DMEM ditambahkan sebagai nutrisi, lakukan penggantian media setiap 2 hari sekali. Kultur sel 2D digunakan sebagai pembanding serta matrik dan media tanpa sel sebagai blanko. Lakukan pengamatan pada hari ke 2, 4 dan 6 .

\section{Viabilitas Sel}

Viabilitas sel diamati menggunakan pewarna trypan blue pada kultur hari ke 2 dan 4 . Ambil $5 \mu \mathrm{L}$ dari kultur warnai dengan $5 \mu \mathrm{L}$ trypan blue, amati sel dengan mikroskop inverted. 


\section{Proliferasi Sel}

Evaluasi proliferasi sel dilakukan dengan menggunakan reagen MTT (3(4,5-dimetiltiazol-2-il)-2,5-dipeniltatrazolium bromide) pada kultur hari ke 6 .

Media pada kultur sel dibuang dan diganti dengan $20 \mu \mathrm{L}$ MTT Reagen, diinkubasi selama 4 jam dalam incubator $\mathrm{CO}_{2}$. Kemudian sebanyak $100 \mu \mathrm{L}$ DMSO dipipetkan kedalam kultur. Pada kultur 3D matriks dihancurkan sehingga dapat melarutkan kristal formazan yang terbentuk. Kemudian lakukan pengukur absorban menggunakan microplate reader $\left(\mathrm{TECAN}^{\circledR}\right)$ pada panjang gelombang 560 $\mathrm{nm}$.

\section{Hasil Penelitian dan Pembahasan}

Hasil

Pada matriks A1 dan A2 sel terlihat membentuk agregat sel di dalam matriks sebagai salah satu ciri kultur sel 3D, pada pengamatan menggunakan mikroskop inverted kultur hari ke 2, 4, dan 6 (Gambar $1)$.

\section{Viabilitas Sel}

Pengamatan menggunakan pewarna trypan blue memperlihatkan agregat sel yang viablepada kultur hari ke 2 dan 4 (Gambar 2).

\section{Proliferasi sel}

Uji proliferasi sel menggunakan reagen MTT menunjukkan nilai absorban pertumbuhan sel pada matriks agarosa $\mathrm{A} 1$, A2, kontrol 2D dan blanko rata-rata absorban masing-masingnya 0,$96 ; 1,22$; 2,03; dan 0,02 (Tabel 1).
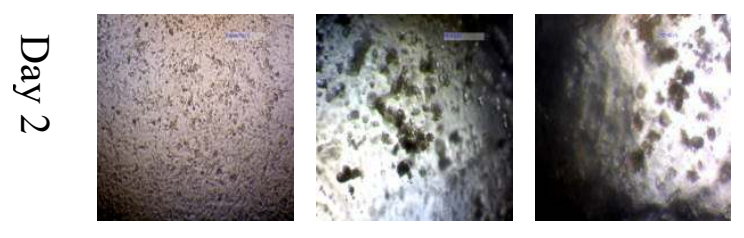

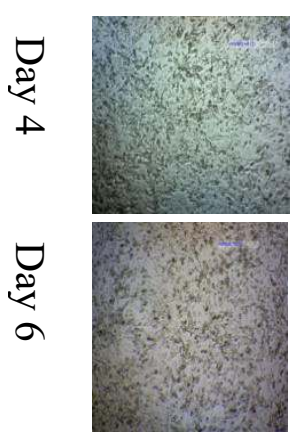

2D

Culture

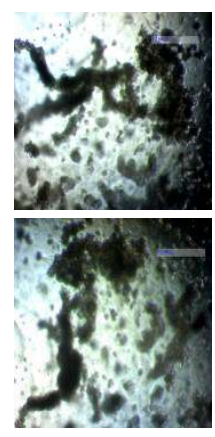

A1

scaffold

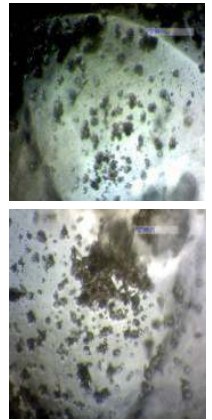

A2
Gambar 1. Pengamatan agregat sel di dalam matriks agarosa $\mathrm{A} 1, \mathrm{~A} 2$, dan kultur 2D menggunakan mikroskop inverted TC $5400^{\circledR}$, Meiji Techno, Japan perbesaran $100 \mathrm{X}$.

\section{Pembahasan}

Hasil penelitian memperlihatkan sel pada kultur membentuk agregat sel. Pada pengamatan menggunakan mikroskop inverted terdapat agregat sel di dalam matriks pada hari ke 2, 4, dan 6 . Agregat sel yang terbentuk tersebar di dalam matriks agarosa secara tidak beraturan (Gambar 1).

Agregat sel merupakan ciri pertumbuhan sel pada kultur 3D yang memperlihatkan sel saling berinteraksi dan berproliferasi. Sel dalam bentuk agregat sel terdiri dari sel-sel dari berbagai fase seperti proliferasi, quiescent, apoptosis, hipoksia dan sel nekrosis. Lapisan terluar paling terekspos dengan media, umumnya terdiri dari keberadaan sel dalam tahapan proliferasi. Bagian inti sel mendapatkan sedikit oksiden, faktor penumbuh, dan nutrisi dari media sehingga cendrung dalam tahapan quiescent at. Heterogenisitas selular ini sangat mirip dengan jaringan in vivo (Edmonson dkk, 2014; Ravi et. al., 2014).

Viabilitas sel diamati dengan menggunakan pewarna trypan blue memperlihatkan sel hidup dan mati. Sel hidup tampak seperti bercahaya dan sel mati tampak menyerap warna biru trypan blue. Sel mati pada agregat sel pada 
matriks mulai tampak pada pengamatan hari ke 4 (Gambar 2).

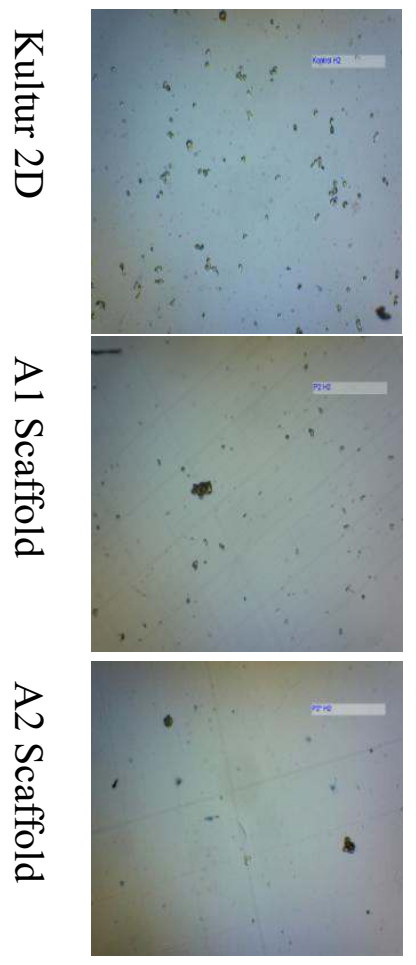

Day 2

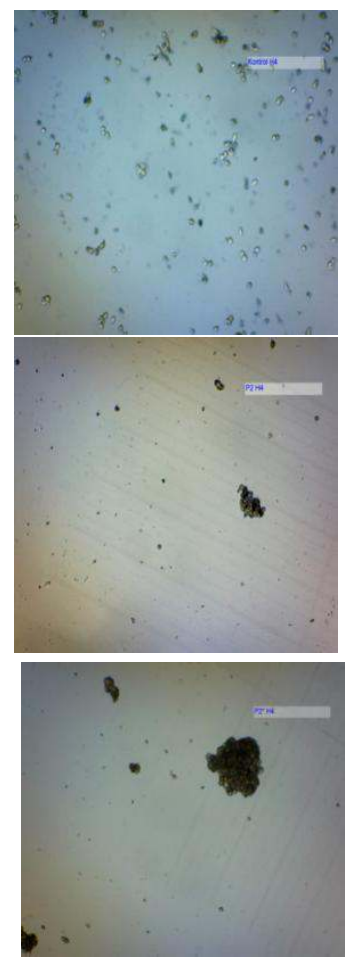

Day 4
Gambar 2. Pengamatan viabilitas sel menggunakan mikroskop inverted agregat sel TC $5400^{\circledR}$, Meiji Techno, Japan perbesaran 100X. Sel viable tidak menyerap warna biru trypan blue.

Kultur sel 3D memperlihatkan viabilitas pada waktu yang singkat $(1-5$ hari). Pada beberapa kasus, kultur 3D terlihat sedikit mengurangi viabilitas ketika waktu kultur diperpanjang, hal ini berhubungan dengan bentuk agregat sebagai akibat kekurangan oksigen dan nutrisi, serta akumulasi limbah pada inti agregat saat berkembang lebih besar (Edmonson dkk, 2014).

Uji proliferasi sel pada penelitian ini menggunakan reagen MTT, hasil berupa nilai absorban yang menunjukkan densitas sel pada kultur. Uji ini dilakukan untuk membuktikan viabilitas sel yang tumbuh dan berkembang di dalam kultur.
Uji MTT merupakan uji kolorimetri yang mengukur viabilitas sel melalui kemampuan sel untuk mereduksi garam tetrazolium kuning menjadi kristal formazan ungu. Kristal formazan ungu yang dihasilkan dilarutkan menggunakan DMSO sebelum pengukuran absorbansi spektrofotometri. DMSO yang digunakan dalam percobaan tidak mempengaruhi pertumbuhan sel. Intensitas yang lebih tinggi dari warna ungu yang dihasilkan menunjukkan jumlah yang lebih tinggi dari sel-sel yang hidup. Dengan demikian, selsel dengan densitas tinggi cenderung menunjukkan absorbansi relatif lebih tinggi dari pada sel dengan densitas rendah. Pengujian ini didasarkan pada pemecahan dari cincin tetrazolium kuning oleh enzim dehidrogenase mitokondria yang hanya aktif dalam sel hidup. MTT adalah teknik yang sangat populer untuk kuantifikasi sel yang hidup dalam kultur karena cepat, nyaman, dan ekonomis (Mosmann, 1983).

Tabel 1. Data absorban uji proliferasi menggunakan reagen MTT

\begin{tabular}{lllcc}
\hline Absorban & \multicolumn{4}{c}{ Jenis Matriks } \\
\cline { 2 - 5 } & Blanko & 2D & A1 & $\mathbf{A 2}$ \\
& 0,01 & 2,18 & 1,08 & 1,98 \\
& 0,02 & 2,37 & 0,86 & 0,92 \\
& 0,02 & 1,53 & 0,94 & 0,76 \\
Rata-rata & $\mathbf{0 , 0 2}$ & $\mathbf{2 , 0 3}$ & $\mathbf{0 , 9 6}$ & $\mathbf{1 , 2 2}$ \\
\hline
\end{tabular}

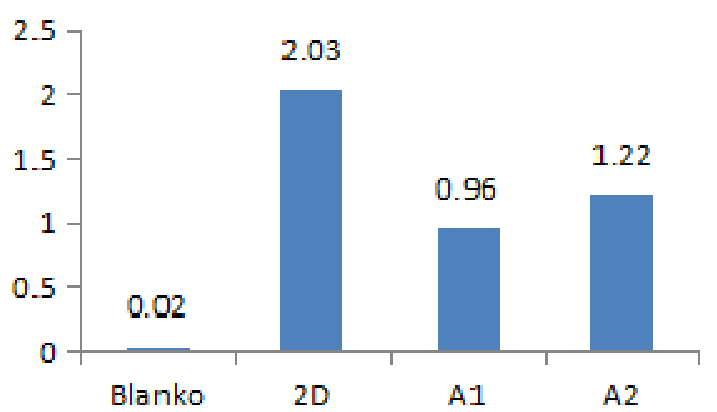

Gambar 3. Diagram nilai absorban uji proliferasi kultur sel 2D dan 3D menggunakan matriks agarosa A1 dan A2. 
Pada penelitian ini tampak pada Gambar 3 nilai rata-rata absorban pada kultur 3D menggunakan matrik agarosa A1 dan A2 (0,96 dan 1,22) lebih kecil dari nilai absorban pada kultur 2D (2,03). Hal ini berbeda dengan penelitian $\mathrm{Xu}$ et. al. (2014) yang menunjukkan pertumbuhan sel pada kultur 3D menggunakan matriks agarosa memberikan nilai absorban yang lebih tinggi dari kultur 2D.

Nilai absorban yang lebih rendah pada kultur 3D dapat disebabkan karna adanya kesalahan saat uji proliferasi seperti tidak optimalnya reagen MTT yang diserap sel viable yang tertutup matriks. Selain itu hal ini dapat juga disebabkan oleh kurangnya nutrisi yang diserap sel dalam pertumbuhan karena terhalang matriks.

\section{Simpulan}

Agarosa A1 dan A2 pada penelitian ini diaplikasikan sebagai matriks pada kultur sel kanker paru line A549. Sel pada kultur 3D membentuk agregat sel di dalam matriks. Agregat sel tumbuh tidak beraturan dengan pertumbuhan yang tidak optimalbila dibandingkan dengan kultur 2D.

\section{Daftar Pustaka}

Adnan AZ, Marlina and Ridho A. Isolation of Agarose and its Application as medium of Gel Electrophoresis Method for HPV (Human Papillomavirus) DNA Identification. Scholars Research Library. 2016. $8(16): 76-82$.

Edmonson R, Jessica JB, Audrey FA and Liju Y. Review Article: ThreeDimensional Cell Culture Systems and Their Applications in Drug Discovery and Cell-Based Biosensors. Assay and Drug Development Technologies Mary
Ann Liebert Inc. 2014. 12 (4):207 218

Li X, Alejadra V, Peng Z and Zhihong N. Microfluidic 3D Cell Culture: Potential Application for TissueBased Bioassays. Bioanalysis. 2012. 4(12): $1509-1525$.

Mishra DK, Chad JC, Yiqun Z, Don LG, Jonathan MK and Min PK. Gene Expression Profile of A549 Cell from Tissue of 4D Model Predict Poor Prognosis in Lung Cancer Patients. Int J Cancer. 2014. 134(4): $789-798$.

Mosmann T. Rapid colorimetric assay for cellular growth and survival: application to proliferation and cytotoxicity assays. Journal of Immunological Methods. 1983. 65(1-2): 55-63.

Ravi M, V Paramesh, SR Kaviya, E. Anuradha, FDP Salomon. 3D Cell Culture System: Adventages and Applications. Journal of Cellular Physiology. 2014. 230(1): 16 -26.

Santos GAA. Manual For Processing Of Agar From Gracillaria. Manila: ASEAN/UNDP/FAO Regional Small-Scale Coastal Fisheries Development Project. 1990.

Xu G, Fuqiang Y, Huayu W, Xuefeng H, Li Z, Jinming Z. In vitro Ovarian Cancer Model Based on Three Dimensional Agarose Hydrogel. Journal of Tissue Engineering. 2014. $5: 1-9$. 